\title{
INTEGRATION OF LEGAL AID ACTIVITY IN LAW SCHOOL CURRICULUM: AN OVERVIEW OF BANGLADESH AND INDIA
}

Farzana Akter, University of Dhaka, Bangladesh*

\begin{abstract}
If law students at the formative stage of their career are exposed to legal aid services, they become motivated to deliver the service when they enter into professional life. The purpose of the present article is to examine the current status of Bangladeshi legal education with regard to the integration of legal aid activity in law school curricula from an international human rights perspective. The article also compares the Bangladeshi legal education with the Indian practice. The article indicates that Bangladeshi students are not adequately motivated, through academic exercise, to use the law for the poor people. As a result, they learn to become mere lawyers to fight legal cases without acquiring adequate service-mindedness to serve the poor people of the community. The article finally recommends that legal education in Bangladesh is
\end{abstract}

*Farzana Akter is Assistant Professor in the Department of Law at the University of Dhaka. 


\section{Practice Report: Teaching and Learning in Clinic}

required to explore the potentials of clinical legal education with a compulsory component of legal aid programme. Moreover, Bangladesh can learn from the standard practices of the Indian law schools.

\section{INTRODUCTION}

Legal education is fundamental in any serious commitment to provide quality legal services to the poor. ${ }^{1}$ In 2007, the Indian National Knowledge Commission reported that the purpose of legal education is to create professional lawyers as well as to provide justice-oriented education for upholding the values of the Constitution. ${ }^{2}$ The justice transformation purpose of legal education, as Pande stated, "can happen only by underscoring the students' role in ensuring that the right of access to justice reaches the resourceless and the poor." ${ }^{3}$ Narrowly, access to justice can be described as providing legal aid which makes judicial remedies available to those with inadequate financial resources by meeting the cost of lawyers and other incidental expenses of the

\footnotetext{
${ }^{1}$ D. L. Rhode, In the Interests of Justice: Reforming the Legal Profession 185-186 (New York, Oxford University Press, 2000).

2 K. P. C. Rao, 'Legal Education in India - How Far the Second Generation Reforms Will Meet the Global Challenges', 46 (9) The Management Accountant 794 (2011). It is also available at: http://kpcrao.com/images/kpcrao/articles/2011/Sep-11-2.pdf (accessed on 14 March 2016) at 102; Final Report of 3-member Committee on Reform of Legal education (2009) at 18. http://www.barcouncilofindia.org/wp-content/uploads/2010/06/3-member-Committee-Report-on-LegalEducation.pdf (accessed on 14 March 2016).

${ }^{3}$ B. B. Pande, 'Moral and Ethical Issues Confronting Students' Legal Aid Clinics in the Outreach of Legal Services to the Resource-less and the Poor', 1 Journal of National Law University, Delhi 48 (2013).
} 
IJCLE - vol 23 no 3

\section{Practice Report: Teaching and Learning in Clinic}

administration of justice. ${ }^{4}$ Therefore, legal aid serves as the contact point between the

law and people who are living in poverty and is crucial in ensuring access to justice. ${ }^{5}$

The United Nations Principles and Guidelines on Access to Legal Aid in Criminal

Justice Systems ${ }^{6}$ (hereinafter the Principles and Guidelines) that provides the

internationally agreed definition of the term 'legal $\mathrm{aid}^{\prime 7}$ requires States to establish a

nationwide legal aid system involving a wide range of stakeholders as legal aid service

providers in order to increase outreach, quality and impact, and facilitate access to legal

aid in all parts of the country. ${ }^{8}$ The Principles and Guidelines particularly mentions the establishment of legal aid clinics in the law department of a university ${ }^{9}$. Such schemes

\footnotetext{
${ }^{4}$ F. Francioni, 'The Development of Access to Justice in Customary Law', in: F. Francioni (ed.), Access to Justice as Human Right 1 (Oxford, Oxford University Press, 2007). Also see, W. C. Vickrey, J. L. Dunn and J. C. Kelso, 'Access to justice: A Broader Perspective', 42 Loyola of Los Angeles Law Review 1153 (2009); G. Blasi, ‘How Much Access? How Much Justice?' 73 Fordham Law Review 865 (2004).

${ }^{5}$ G. Knaul, Report of the Special Rapporteur on the Independence of Judges and Lawyers, A/HRC/23/43 (15 March 2013), paras. 27 and 35.

http://www.wavenetwork.org/sites/default/files/UN\%20Special\%20Rapporteur\%20on\%20the\%20Independence\%20of\%20J udges\%20and\%20Lawyers.pdf (accessed on 2 March 2016).

${ }^{6}$ General Assembly Resolution, A/RES/67/187 (28 March 2013).

http://www.un.org/en/ga/search/view_doc.asp?symbol=A/RES/67/187 (accessed on 1 March 2016).

${ }^{7}$ Supra, note 5 at para. 26. The Principles and Guidelines construes the term 'legal aid' to include "legal advice, assistance and representation for victims and for arrested, prosecuted and detained persons in the criminal justice process, provided free of charge for those without means or when the interests of justice so require". Furthermore, "legal aid is intended to include the concepts of legal education, access to legal information and other services provided for persons through alternative dispute resolution mechanisms and restorative justice processes". Annex, Introduction, para. 8, the United Nations Principles and Guidelines on Access to Legal Aid in Criminal Justice Systems.

${ }^{8}$ Annex, Introduction, paras. 9-10; Guideline 12, the United Nations Principles and Guidelines on Access to Legal Aid in Criminal Justice Systems.

${ }_{9}$ Annex, Principle 14 and Guideline 16, the United Nations Principles and Guidelines on Access to Legal Aid in Criminal Justice Systems.
} 


\section{Practice Report: Teaching and Learning in Clinic}

enable students to provide free legal assistance, assist in the preparation of cases and even represent clients in court proceedings usually under the supervision of a qualified lawyer or faculty staff member. In this context, the present paper examines the current status of Bangladeshi legal education with regard to the integration of legal aid activity in law school curricula from an international human rights perspective. The author, therefore, first looks at the international human rights instruments elucidating such States' obligation. In analysing Bangladeshi legal education, the author compares the system with Indian legal education. There are reasons for choosing India's practice for the comparative analysis. India and Bangladesh share not only a similar historical background, ${ }^{10}$ but also similar legal traditions - both countries follow the common law system. Moreover, there is commonality between the countries in terms of social and economic standards, and linguistic and cultural practices. ${ }^{11}$ More importantly, both India and Bangladesh have established respective national legal aid systems in order to enable those living in poverty to access the formal court system. Thus Indian and

\footnotetext{
${ }^{10}$ Bangladesh and India both were under British colonial rule. By 1947, the British Empire in India expired. This created two separate States: India and Pakistan. The division was mainly founded along religious lines which constituted a Muslim majority in Pakistan and a Hindu majority in India. Pakistan was further divided into two parts in the east (East Bengal, which became Bangladesh in 1971) and in the west (western Punjab). I. Talbot and G. Singh, The Partition of India 1-4 (Cambridge, Cambridge University Press, 2009); W.V. Schendel, A History of Bangladesh 88-130 (Cambridge, Cambridge University Press, 2009); The Road to Partition 1939-47. http://www.nationalarchives.gov.uk/education/topics/the-road-topartition.htm (accessed on 14 March 2016).

$11 \quad$ India-Bangladesh Relations (January, 2013). http://www.mea.gov.in/Portal/ForeignRelation/Bangladesh Brief.pdf (accessed on 14 March 2016).
} 


\section{Practice Report: Teaching and Learning in Clinic}

Bangladeshi legal aid systems are functionally equivalent and it is relevant to look at Indian practice to see whether Bangladesh can learn from it.

\section{OBLIGATION OF STATES TO INTEGRATE LEGAL AID ACTIVITY IN LAW SCHOOL CURRICULUM UNDER THE INTERNATIONAL HUMAN RIGHTS INSTRUMENTS}

The structure of legal education represents a combination of the State's public policy as well as academic self-interest of the intending lawyers. ${ }^{12}$ According to Jeeves and Macfarlane, the educational experience of the potential lawyers plays a significant role in his or her aims and expectations for future practice. ${ }^{13}$ Therefore, legal education must mobilise the necessary legal personnel to serve a wider public and a broad range of interests on the one hand, and to improve the quality of legal services to the poor on the other. ${ }^{14}$ Legal aid activity is integrated into law school curricula as a part of the clinical legal education programmes in order to cultivate professional skills and service orientation among the potential lawyers. ${ }^{15}$ The purpose of clinical legal education,

\footnotetext{
12 Supra note 1 at p. 187.

${ }^{13}$ M. Jeeves and J. Macfarlane, 'Rethinking Legal Education', in: J. Cooper and R. Dhaveen (eds.), Public Interest Law 394 (Oxford/New York, Basil Blackwell, 1986).

14 Supra note 1 at pp. 185-86.

${ }^{15}$ A. Klijn, 'Dutch Legal Services Quality Incentives: The Allegedly "perverse" Effects of the 1994 Legal Aid Act', 33(2) University of British Columbia Law Review 438 (2000); V.R.K. Iyer, 'Law and the People' 115 (1972) cited in F. S. Bloch and I. S. Ishar, 'Legal Aid, Public Service and Clinical Legal Education: Future Directions from India and the United States', 12 Michigan Journal of International Law 98 (1990).
} 


\section{Practice Report: Teaching and Learning in Clinic}

therefore, is to develop the perception, skills and sense of responsibility of the students for their professional life. ${ }^{16}$ It enables law students to comprehend and assume the responsibility for the protection of individual rights, reform of the law, equitable distribution of legal services in society and for the protection of public interest. ${ }^{17}$ Thus, clinical legal education provides the students opportunities not only for professional and intellectual development; it also prepares them to practise law as socially and professionally responsible lawyers. ${ }^{18}$

Wilson states that law students in clinics provide legal services to the poor, and it allows them to get in close contact with the problems of that segment of society. ${ }^{19}$ This kind of exposure helps train the students to adequately respond to the needs of poor justice seekers ${ }^{20}$ and to pursue careers of public interest. ${ }^{21}$ Therefore, clinical legal

\footnotetext{
${ }^{16}$ S. P. Sarker, 'Empowering the Underprivileged: The Social Justice Mission for Clinical Legal Education in India', 19 International Journal of Clinical Legal Education 321 (2013); K. Archana, 'Practicability of Clinical Legal Education in India - An Overview', 4 (26) Journal of Education and Practice 157 (2013).

${ }_{17}$ N.R.M. Menon, Clinical Legal Education: Concept and Concerns, A Handbook on Clinical Legal Education 1 (Lucknow, Eastern Book Company, 1998).

18 S. P. Sarker, supra note 16 at p. 321; K. Archana, supra note 16 at p. 157.

${ }^{19}$ R. J. Wilson, 'Training for Justice: The Global Reach of Clinical Legal Education', 22(3) Penn State International Law Review 423(2004).

${ }^{20}$ A. Klijn, supra note 15 at p. 438; S. P. Sarker, supra note 16 at p. 321; K. Archana, supra note 16 at p. 157; F. S. Bloch and I. S. Ishar, supra note 15 at p. 96.

${ }^{21}$ Barry has stated it more clearly, "Clinics expose students to the impact that the practice of law has on people. No one should pretend that they are prepared to practice without a sense of this impact and a constructive way to think about it... It is law schools that must foster a contextual understanding of what lawyers should do to meet the needs of the country. This means connecting students with communities and involving them in creative solutions that focus on the common good." M. Barry, "Clinical Legal Education in the Law University: Goals and Challenges', 2007 International Journal of Clinical Legal Education 30 (2007).
} 


\section{Practice Report: Teaching and Learning in Clinic}

education serves a two-fold purpose: first, it provides legal services to the poor and trains students to learn about the skills of lawyering, and second, it creates a publicminded legal profession in the future. ${ }^{22}$ Moreover, as Pande states, students' involvement in various components of the legal aid programme that includes activities associated with the creation of legal awareness or legal literacy, paralegal work, and other law reform activities is crucial, and has a stronger impact on their successful operation. ${ }^{23}$ States are, therefore, required to take appropriate measures, as part of a nationwide legal aid system to encourage the support and establishment of law clinics in universities as well as to provide incentives to allow students to practise in the court under the supervision of a senior lawyer or a law professor. ${ }^{24}$

The obligation concerning the integration of legal aid activity in the legal education of the country has been recognised in various international human rights instruments. These instruments consist of various United Nations (UN) documents involving UN General Assembly resolutions and standards of behavior. The UN documents are

\footnotetext{
${ }^{22}$ R. J. Wilson, supra note 19 at p. 424; According to Rhode, "If we want lawyers to see public service as a professional responsibility, that message must start in law school." D. L. Rhode, Access to Justice 19 (Oxford, Oxford University Press, 2004).

${ }^{23}$ B.B. Pande, supra note 3 at p. 41. Also see, Government of India and UNDP India, A Study of Law School Based Legal Services Clinics (2011) at 23.

http://www.in.undp.org/content/dam/india/docs/a study of law school based legal services clinics.pd $\underline{\mathrm{f}}$ (accessed on 12 March 2016).

${ }^{24}$ Guidelines 11, 12 and 16, the United Nations Principles and Guidelines on Access to Legal Aid in Criminal Justice Systems.
} 


\section{Practice Report: Teaching and Learning in Clinic}

considered the most authoritative and comprehensive in the respective fields. ${ }^{25}$ They are important sources for interpreting and understanding States' international legal obligations. They also provide guidance or models for domestic laws that are able to assist policy makers to realise rights at the national level ${ }^{26}$. Among the above-mentioned documents, the UN Draft Declaration on the Independence of Justice (the Singhvi Declaration $)^{27}$ in its Article 78 stipulates that legal education is required to promote the awareness of the ideals and ethical duties of lawyers and of human rights and fundamental freedoms recognised by national and international law. As far as the responsibility of lawyers is concerned, the Declaration requires States to undertake legal education programmes that have regard to the social responsibilities of lawyers including co-operation in providing legal services to the poor. ${ }^{28}$ The Basic Principles on the Role of Lawyers ${ }^{29}$ acknowledges that lawyers have the obligation to uphold human rights and fundamental freedoms recognised by national and international law in

\footnotetext{
${ }^{25}$ Richard J. Wilson, 'Principles, Sources and Remedies for Violation of the Right to Legal Assistance in International Human Rights Law', in: International Legal Aid and Defender System Development Manual 21 (USA, National Legal Aid and Defender Association, 2010). http://www.nlada.org/Defender/Defender Publications/International Manual 2010 (accessed on 14 March 2016).

${ }^{26}$ C. Chinkin, 'Sources', in: D. Moeckli, S. Shah, S. Sivakumaran, D. Harris (eds.), International Human Rights Law 92 (Oxford, Oxford University Press, 2013).

${ }^{27}$ Resolution 1989/32, the UN Sub-Commission on Prevention of Discrimination and Protection of Minorities. http://www.cristidanilet.ro/docs/Shingvi\%20Declaration.pdf (accessed on 14 March 2016).

${ }_{28}$ Article 79, the UN Draft Declaration on the Independence of Justice (the Singhvi Declaration).

${ }^{29}$ Adopted by the Eighth United Nations Congress on the Prevention of Crime and the Treatment of Offenders, Havana, Cuba (27 August to 7 September 1990).

http://www.ohchr.org/EN/ProfessionalInterest/Pages/RoleOfLawyers.aspx (accessed on 11 February 2016).
} 
IJCLE - vol 23 no 3

\section{Practice Report: Teaching and Learning in Clinic}

protecting the rights of their clients and in promoting the cause of justice. ${ }^{30}$ It, therefore, requires the educational institutions to ensure that lawyers have appropriate education and training and are made aware of the ideals and ethical duties appropriate to them and of human rights and fundamental freedoms recognised by national and international law. ${ }^{31}$ As regards ethical duty, it is commonly said that lawyers have a duty to render legal services to the poor. ${ }^{32}$ However, such obligation is not restricted to the moral principle only; it also conjoins with the professional responsibility of lawyers. This is because access to legal services is considered a 'fundamental need'33 and the legal profession enjoys a monopoly on the delivery of legal services. ${ }^{34}$ In other words, the practice of law requires a distinct level of skill and training and lawyers possess such qualities. This imposes a special obligation on them to render legal services to the

\footnotetext{
${ }^{30}$ Principle 14, Basic Principles on the Role of Lawyers.

${ }^{31}$ Principle 9, Basic Principles on the Role of Lawyers.

${ }^{32}$ M. S. Jacobs,' Pro Bono Work and Access to Justice for the Poor: Real Change or Imagined Change?' 48 Florida Law Review 511-512 (1996); S. Bretz, 'Why Mandatory Pro Bono is a Bad Idea', 3 Georgetown Journal of Legal Ethics 623 (1990); L.S. Tudzin, 'Pro Bono Work: Should it be Mandatory or Voluntary', 12 Journal of the Legal Profession 112 (1987); S. B. Rosenfeld, 'Mandatory Pro Bono: Historical and Constitutional Perspectives', 2 Cardozo Law Review 257-259 (1981).

${ }^{33}$ D. L. Rhode (a), 'Pro Bono in Principle and in Practice', 53(3) Journal of Legal Education 430-431 (2003); D. L. Rhode (b), 'Cultures of Commitment: Pro bono for Lawyers and Law Students', 67(5) Fordham Law Review 2418 (1999).

${ }^{34}$ L. Sossin, 'The Public Interest, Professionalism and Pro bono Publico', 46 Osgoode Hall Law Journal 140, 147 (2008); D. L. Rhode (b), supra note 33 at p. 2419; M. S. Jacobs, Supra note 32 at p. 511; B. F. Christensen, 'The Lawyer's Pro Bono Publico Responsibility', 1981(1) American Bar Foundation Research Journal 15-16 (1981); J. Bitowt, 'The Pro Bono Debate', 9 Student Lawyer 38(1980).
} 


\section{Practice Report: Teaching and Learning in Clinic}

poor. ${ }^{35}$ Therefore, it is significant to include legal services in the law school curriculum in order to create a service-mindedness among the students towards legal aid work as well as to uphold their moral and professional obligation to provide legal services to the poor. ${ }^{36}$

The United Nations Principles and Guidelines on Access to Legal Aid in Criminal Justice was adopted by the UN General Assembly consisting of all the UN Member States in December 2012. It has become a benchmark for access to justice because it is the first international instrument that absolutely concentrates on legal aid. ${ }^{37}$ The Principles and Guidelines is drawn from international standards and recognised best practice, and presents a progressive, ${ }^{38}$ complete and realistic model of legal aid that considers the great variety among legal systems and socioeconomic conditions. ${ }^{39}$ It is, thus, comprehensive in nature and introduces a complete programme for an effective and fair

\footnotetext{
${ }^{35}$ D. L. Rhode (b), supra note 33 at p. 2419; J. Giddings, 'Legal Aid Services, Quality and Competence: Is Near Enough Good Enough and How Can We Tell What's What?' 1 Newcastle Law Review 67-68 (1996); Z. I. Macaluso, 'That's O.K., This One's on Me: A Discussion of the Responsibilities and Duties Owed by the Profession to Do Pro Pono Publico work', 26 University of British Columbia Law Review 65 (1992).

${ }^{36}$ M. J. Toll and J. L. Allison, 'Advocates for the Poor', 46 Denver Law Journal 85 (1969).

${ }^{37} \mathrm{~A}$. Willems, 'The United Nations Principles and Guidelines on Access to Legal Aid in Criminal Justice Systems: A Step toward Global Assurance of Legal Aid?' 17(2) New Criminal Law Review 185 (2014).

${ }^{38}$ Open Society Justice Initiatives, Fact Sheet: UN Principles and Guidelines on Access to Legal Aid in Criminal Justice Systems.

http://www.opensocietyfoundations.org/sites/default/files/factsheet-un-principles-guidelines20130213.pdf (accessed on 15 March 2016).

${ }^{39}$ Recital 10, the United Nations Principles and Guidelines on Access to Legal Aid in Criminal Justice Systems.
} 


\section{Practice Report: Teaching and Learning in Clinic}

legal aid scheme. ${ }^{40}$ The Principles and Guidelines allows States to work with a wide range of legal aid service providers to increase outreach, quality and facilitate access to legal aid and therefore, has taken into consideration different models for the provision of legal aid. One of these models involves the establishment of law clinics in the law department of a university. As mentioned earlier, law clinics provide students an opportunity to get exposure to the problems of the poor and provide free legal assistance to them. This is an integrated approach between the government and other organisations and is able to ensure the maximum coverage of the legal aid beneficiaries. Therefore, as the Principles and Guidelines requires, States are responsible for taking appropriate measures to encourage the support and establishment of such clinics in university law departments and provide incentives to allow students to practise in court under the supervision of a senior lawyer or a law professor. ${ }^{41}$

In sum, international human rights norms acknowledge the role of law students in rendering legal aid to the poor. Therefore, integration of legal aid activity in the law school curriculum is crucial and is able to motivate prospective lawyers towards legal aid work. This ultimately can impact on the outreach and quality of the service.

\footnotetext{
40 Supra note 37 at pp. 190,198.

${ }^{41}$ Guidelines 11, 12 and 16, the United Nations Principles and Guidelines on Access to Legal Aid in Criminal Justice Systems.
} 
IJCLE - vol 23 no 3

\section{Practice Report: Teaching and Learning in Clinic}

\section{LEGAL AID ACTIVITY IN INDIAN LAW SCHOOLS}

In 1976, the Constitution (forty-second amendment) Act ${ }^{42}$ inserted Article 39-A in the Indian Constitution. Article 39A refers to a direct and express provision of legal aid as one of the Directive Principles of State policy and provides that States shall secure that the operation of the legal system promotes justice on the basis of equal opportunity, and shall in particular, provide free legal aid, by suitable legislation or schemes or in any other way, to ensure that opportunities for securing justice are not denied to any citizen by reason of economic or other disability. Articles $14^{43}$ and $22(1)^{44}$ also make it obligatory for the State to ensure equality before the law and a legal system which promotes justice on the basis of equal opportunity for all. In 1987, India established its national legal aid system with the adoption of the Legal Services Authorities Act (hereinafter LSAA). ${ }^{45}$ The LSAA gives a statutory base to legal aid programmes throughout the country in a uniform pattern. For this, a nationwide network has been

42 The Constitution (forty-second amendment) Act, 1976.

http://india.gov.in/my-government/constitution-india/amendments/constitution-india-forty-secondamendment-act-1976 (accessed on 15 March 2016). To note, the Republic of India is governed in terms of the Constitution of India which was adopted by the Constituent Assembly on 26th November 1949 and came into force on 26th January 1950.

http://india.gov.in/my-government/constitution-india (accessed on 15 March 2016).

${ }_{43}$ Article 14 reads, "The State shall not deny to any person equality before the law or the equal protection of the laws within the territory of India".

${ }^{44}$ Article 22(1) states, "No person who is arrested shall be detained in custody without being informed, as soon as may be, of the grounds for such arrest nor shall he be denied the right to consult, and to be defended by, a legal practitioner of his choice".

${ }^{45}$ Act 39 of 1987. 


\section{Practice Report: Teaching and Learning in Clinic}

envisaged under the Act for providing legal aid and assistance. The National Legal Services Authority (hereinafter NALSA) is the apex body constituted under Section 3 of the Act.

Legal aid activity has become part of the curriculum in Indian law schools through clinical legal education programmes. At present clinical legal education is a mandatory part of India's legal education that traces its origins to both the legal aid and legal education reform movements with a view to improving the quality of law practice as well as making lawyers aware of their professional and public responsibility. ${ }^{46}$ The involvement of Law Colleges in legal aid activity commenced in India when the legal aid movement gained momentum in the 1960s. It was premised on the assumption that law schools could play a significant role in providing legal services and that would be possible through Legal Aid Clinics. ${ }^{47}$ Moreover, most members of the Indian legal community including law teachers, the bar, the bench and legal aid experts have admitted that isolation or exclusion of law schools from legal aid programmes would

\footnotetext{
${ }^{46}$ S. P. Sarker, supra note 16 at p. 321; K. Archana, Supra note 16 at p. 157; F. S. Bloch and I. S. Ishar, supra note 15 at p. 96.

${ }^{47}$ F. S. Bloch and I. S. Ishar, supra note 15 at p. 96; F. S. Bloch and M. R. K. Prasad, 'Institutionalizing a Social Justice mission for Clinical Legal Education: Cross-national Currents from India and the United States', 13 Clinical Law Review 166 (2006); S. P. Sarker, supra note 16 at p. 321.
} 


\section{Practice Report: Teaching and Learning in Clinic}

not serve to achieve the aim of the service, rather would be frustrating for legal aid, legal education, and the legal profession. ${ }^{48}$

Various reports of the Law Commission and the Ministry of Law and Justice of India have acknowledged the significance of legal education in establishing an effective legal aid system. ${ }^{49}$ These reports have called upon law students to engage in public service while in law schools. In 1981, the government appointed the Committee for Implementing Legal Aid Schemes. The Committee insisted that court-oriented legal aid programmes alone are not adequate to provide social justice in India. It, therefore, placed more emphasis on other components of the legal aid system, for example, the promotion of legal literacy, the organisation of legal aid camps to carry legal services to people's doorsteps, training paralegals to support legal aid programmes, establishing legal aid clinics in law schools and universities, and bringing class actions through public interest litigation. ${ }^{50}$

\footnotetext{
${ }^{48}$ F. S. Bloch and I. S. Ishar, supra note 15 at p. 97; F. S. Bloch and M. R. K. Prasad, Supra note 48 at p. 166; Jethmalani, 'Objectives of Legal Education', in: S. K. Agrawala, S. P. Sathe and P. K. Irani (eds.), Legal Education in India: Problems and Perspectives 52, 56-57 (University of Poona, N. M. Tripathi, 1973).

${ }^{49}$ For instance, Fourteenth Report of the Law Commission of India (1958), 184th Report of the Law Commission of India on the Legal Education and Professional Training and Proposals for Amendments to the Advocates Act, 1961 and the University Grants Commission Act, 1956 (December 2002), Expert Committee on Legal Aid (1973) and Committee on National Juridicare: Equal Justice-Social Justice (1976).

${ }^{50}$ S. P. Sarker, supra note 16 at p. 325; F. S. Bloch and M. R. K. Prasad, supra note 48 at p. 175.
} 


\section{Practice Report: Teaching and Learning in Clinic}

The Bar Council of India also plays a significant role in the integration of legal aid activity in law schools. In 1997, the Bar Council issued a circular ${ }^{51}$ that makes legal aid activity an integral part of the academic curriculum since the academic year 1998-99.52 To be more specific, the Bar Council has mandated for all Indian law schools four practical papers under the clinical component in the curriculum. One of these papers is specifically designed to provide various services to society including Lok Adalat, legal aid camps, legal literacy and paralegal training in order to involve the students with the community. ${ }^{53}$ In 2008, the Council approved the rules on "Standards of Legal Education and Recognition of Degrees in Law". ${ }^{54}$ The rules mandated all law colleges to "establish and run a legal aid clinic under the supervision of a senior faculty member". ${ }^{55}$ In 2010, the Bar Council reiterated the same in its Inspection Manual 2010. ${ }^{56}$ The National Legal

\footnotetext{
${ }^{51}$ Bar Council of India, Circular No. 4/1997 cited in F. S. Bloch and M. R. K. Prasad, supra note 48 at p. 180; Promoting Clinical Legal Education in India: A Case Study of the Citizen Participation Clinic, Joint ReportCornell University Law School and Jindal Global Law School (2012) at 8. http://www.gaje.org/wp-content/uploads/2012/09/Cor-JGLS-web low.pdf (accessed on 5 March 2016). 52 S. P. Sarker, Supra note 16 at p. 326.

${ }^{53}$ S. P. Sarker, supra note 16 at p. 326; F. S. Bloch and M. R. K. Prasad, supra note 48 at p. 180; J. Schukoske and R. Adlakha, 'Enhancing Good Governance in India: Law Schools and Community-University Engagement', 3 Journal of Indian Law and Society 207 (2012). http://jils.ac.in/wpcontent/uploads/2012/11/jane-roopali1.pdf (accessed on 4 March 2016).

${ }^{54}$ Department of Justice, Government of India and UNDP India, Conference Report, International Conference on Equitable Access to Justice: Legal Aid and Legal Empowerment, New Delhi, India (17 - 18 November 2012) at 21. http://www.in.undp.org/content/dam/india/docs/DG/equitable-access-to-justice-legalempowerment-legal-aid-and-making-it-work-for-the-poor-and-marginalised.pdf (accessed on 15 March 2016).

${ }^{55}$ Ibid.

56 The Bar Council of India's Inspection Manual (2010) at 35.
} 


\section{Practice Report: Teaching and Learning in Clinic}

Services Authority (Legal Aid Clinics) Scheme, $2011^{57}$ is also relevant and requires law colleges and law universities to set up permanent legal aid clinics attached to their institutions that function with the co-ordination of State Legal Service Authorities. ${ }^{58}$

Thus Indian legal education places considerable emphasis on clinical legal education so that students can learn the law while acquiring professional skills. As a component of this programme, students are expected to realise the role of legal aid in the society, its beneficiaries, and the nature of their problems. A study supported by the Government of India and UNDP Project on Access to Justice found that nearly 82 percent of the colleges have an assigned faculty to conduct legal aid activity. Yet it is not effective because legal aid activity is still a non-credit, extra-curricular activity in Indian law schools. ${ }^{59}$ The study further revealed that several legal aid clinics were started merely to satisfy the mandatory requirement prescribed by the Bar Council. Clinics do not have appropriate functional structure or policy on the kind of services they would offer. ${ }^{60}$

http://www.barcouncilofindia.org/wp-content/uploads/2010/06/Inspection-Manual.pdf (accessed on 5 March 2016).

${ }^{57}$ https://www.google.com.bd/url?sa=t\&rct=j\&q=\&esrc=s\&source=web\&cd=1\&ved=0ahUKEwiejO3c0MLL AhWXjo4KHQuBDeYQFggaMAA\&url=http\%3A\%2F\%2Fnalsa.gov.in\%2FSchemes\%2FNALSA\%2520LE GAL\%2520AID\%2520CLINICS\%2520REGULATIONS\%2C\%25202011.doc\&usg=AFQjCNH1cGM1192fOT rCtWRFvcPGd7Binw\&bvm=bv.116636494,d.c2E\&cad=rja (accessed on 15 March 2016).

58 Paras 24-26.

${ }^{59}$ Government of India and UNDP India, A Study of Law School Based Legal Services Clinics (2011) at 2, 4547.

http://www.in.undp.org/content/dam/india/docs/a study of law school based legal services clinics.pd $\underline{\mathrm{f}}$ (accessed on 15 March 2016).

${ }^{60}$ Also see, B.B. Pande, Supra note 3 at p. 36. 


\section{Practice Report: Teaching and Learning in Clinic}

Most of the activities of the clinics are limited to organising a few Legal Literacy Camps ${ }^{61}$ It is also found that the law colleges do not make adequate effort to inform the community about their existence and the availability of services. As regards providing legal advice or participation in client interviewing, the performance of the colleges is far from the desired level. ${ }^{62}$ The situation is similar in offering paralegal services and law reform. According to the above-mentioned study, one of the drawbacks in the clinical legal education of India is the inability of full-time law teachers and students to appear in court on behalf of legal aid clients. ${ }^{63}$

However, the same study also found standard practices in seven law schools that are engaged in a variety of legal aid activities. ${ }^{64}$ For instance, V.M. Salgaocar College and Jindal Law School work on Rural Good Governance. Symbiosis Law School has been conducting a unique programme to provide legal aid in two ways: it has created a Legal Aid Fund and deployed a few lawyers to a selected village. Again the Indian Law Society, Pune established clinics both inside and outside its campus. Students of JSS Law College, Mysore conduct a huge legal literacy programme. Other activities by these colleges include paralegal services, public surveys, community empowerment

\footnotetext{
${ }^{61}$ Supra note 59 at 2, 45-47.

62 Ibid.

${ }^{63}$ Ibid.

${ }^{64}$ Supra note 59 at $3,47-57$.
} 


\section{Practice Report: Teaching and Learning in Clinic}

programmes, implementation of Social Welfare Programmes, Prison Clinics and Consumer Clinics. ${ }^{65}$ The study, therefore, recommends that these exemplary practices should be adopted in different parts of the country.

In short, the Indian legal aid system provides law schools a unique opportunity to achieve the social justice mission of legal education. However, this mission has not yet been achieved due to various factors including the lack of adequate financial and logistical support, lack of skilled academic staff, and other related provisions. Despite these shortcomings, certain activities of particular Indian law schools have the potential of addressing the values of legal aid and of the social justice mission in the broad sense. These examples can be followed by other Indian states as well as other countries with similar socio-economic backgrounds in order to develop their legal education and the legal aid system.

\section{LEGAL AID ACTIVITY IN BANGLADESHI LAW SCHOOLS}

In Bangladesh, the right of equality before the law is guaranteed in Article 27 of the Constitution. The right to a fair trial is also ensured. ${ }^{66}$ Yet the formal legal system is inaccessible to the poor due to a variety of factors - they include the enormous cost of

65 Ibid.

${ }^{66}$ Article 33 of the Constitution of Bangladesh. 


\section{Practice Report: Teaching and Learning in Clinic}

engaging a lawyer, cost for travelling long distances, paying court fees, collecting evidence and judgements, complexity of law and legal institutions and others. ${ }^{67}$ According to Khair, the need for legal aid to the poor in Bangladesh has been strongly pursued over the years to enable them to access justice. ${ }^{68}$ However, organised State intervention towards legal aid is not very old in the country. ${ }^{69}$ The first initiative was taken in 1994 when the government introduced a legal aid fund to be distributed through the District and Sessions Judge of each district. ${ }^{70}$ In 1997, the government established a National Legal Aid Committee according to a Resolution of the Ministry of Law, Justice and Parliamentary Affairs. ${ }^{71}$ The committee was chaired by the Minister of the Ministry of Law, Justice and Parliamentary Affairs. The Resolution also involved District Committees that were to be chaired by the District and Sessions Judges. However, there is a lack of official data on the actual coverage of this mechanism. ${ }^{72}$ In 2000, the government enacted the Legal Aid Services Act ${ }^{73}$ (hereinafter LASA) to put the

\footnotetext{
${ }^{67}$ S. Khair, Legal Empowerment for the Poor and the Disadvantaged: Strategies Achievements and Challenges. Experiences from Bangladesh 43-51 (Dhaka, Department of Justice Canada's CIDA Legal Reform Project in Bangladesh, 2008).

${ }^{68}$ Ibid at p. 212.

69 S. Muralidhar, Law, Poverty and Legal Aid: Access to Criminal Justice 357 (New Delhi, LexisNexis/Butterworth, 2004); S. Khair, Supra note 67 at p. 221.

${ }^{70}$ N. A. Chowdhury and S. Malik, 'Awareness on Rights and Legal Aid Facilities: The First Step to Ensuring Human Security', in: Human Security in Bangladesh: In Search of Justice and Dignity 42 (United Nations Development Programme (UNDP), Bangladesh, 2002).

${ }^{71}$ S.R.O .No. 74-Law/1997, dated 19 March 1997.

72 N. A. Chowdhury and S. Malik, Supra note 70 at pp. 43-44.

${ }^{73}$ Aingoto Sohayota Prodan Ain, Act No. VI of 2000.
} 


\section{Practice Report: Teaching and Learning in Clinic}

legal aid activities on a firm footing. The National Legal Aid Services Organization (hereinafter NLASO) was established for carrying out the purposes of the LASA in pursuance of its section 3(1). ${ }^{74}$ Moreover, the LASA creates a nationwide network for the administration of legal aid services and therefore accommodates provisions for various Committees at the national and district level.

As far as the integration of legal aid activity in law school curricula is concerned, clinical legal education programmes are absent in Bangladesh. This prevents law schools from providing a unique opportunity to train prospective lawyers to approach the law with the commitment and skills to render justice to those living in poverty. However, in the early-1990s three major public universities ${ }^{75}$ of Bangladesh launched clinical legal education programmes on an ad hoc basis with the sponsorship of the Ford Foundation. ${ }^{76}$ The underlying purpose of these programmes was to train law

\footnotetext{
${ }^{74}$ S.R.O.No.146-Law/2000.

${ }^{75}$ S. Golub, 'From the Village to the University: Legal Activism in Bangladesh', in: M. McClymont and S. Golub (eds.), Many Roads to Justice 128, 144-145 (USA, the Ford Foundation, 2000); R. Hoque, 'Teaching Law for Development? Legal education: Needs major overhaul', The Daily Star, Dhaka, May 5, 2012. http://archive.thedailystar.net/law/2012/05/01/index.htm (accessed on 24 Feb 2016).

${ }^{76}$ Law Commission People's Republic of Bangladesh, Review of Legal Education in Bangladesh, Final Report, Dhaka 2006 at 41.

http://r.search.yahoo.com/ ylt=AwrTcc6ZIOhWPUMAOOknnIlQ; ylu=X3oDMTEybDg3MTJ1BGNvbG8 DZ3ExBHBvcwMxBHZ0aWQDQjE3MThfMQRzZWMDc3I$\angle \mathrm{RV}=2 / \mathrm{RE}=1458082073 / \mathrm{RO}=10 / \mathrm{RU}=\mathrm{http} \% 3 \mathrm{a} \% 2 \mathrm{f} \% 2 \mathrm{fwww}$.lawcommissionbangladesh.org\%2freports\%2fre port $84 \% 2$ fFinal\%2520Report\%2fReview\%2520of\%2520Legal\%2520Education\%2520in\%2520BangladeshFinal\%2520Report.doc/RK=0/RS=niiVruXv5jOuPwnldeNTwZnPUxo- (accessed on 15 March 2016).
} 


\section{Practice Report: Teaching and Learning in Clinic}

graduates to get involved in the social and developmental causes of society. ${ }^{77}$ In 2009 , the Law Commission of Bangladesh recommended the government incorporate compulsory clinical legal education in law schools; the main purpose of this programme would be to render legal services to the poor. ${ }^{78}$ However, there is a lack of substantial effort on the part of successive governments to put the recommendation into effect. At present only one university, University of Chittagong, offers clinical legal education as a component of its syllabus, but the clinic has confined its activities mostly to the organisation of various workshops and lectures and therefore has virtually disdained its clinical character. ${ }^{79}$ In short, the combination of pro-justice and vocational orientations in the Bangladeshi legal education is currently absent. ${ }^{80}$ In other words, the students are not adequately motivated, through academic exercise, to use the law for the poor people. ${ }^{81}$ As a result, they learn to become mere lawyers to fight legal cases

\footnotetext{
77 R. Hoque, Supra note 75.

${ }^{78}$ http://www.lawcommissionbangladesh.org/reports/92.pdf (accessed on 13 May 2014).

${ }^{79}$ R. Hoque, Supra note 75.

${ }^{80}$ Ibid.

${ }^{81}$ C. Farid, 'New Paths to Justice: A Tale of Social Justice Lawyering in Bangladesh', 31(3) Wisconsin International Law Journal 459 (2013-2014); R. Hoque, Room for Improvement.

http://www.dandc.eu/en/article/law-schools-must-do-much-better-job-bangladesh (accessed on 14 March 2016).
} 


\section{Practice Report: Teaching and Learning in Clinic}

without acquiring adequate service-mindedness to serve the poor people of the community ${ }^{82}$ It also limits the coverage of legal aid activities in the country.

However, as discussed earlier, international human rights norms recognise that lawyers have the obligation to protect the rights of their clients and promote the cause of justice. As a result, they call on States to establish legal education programmes that include appropriate training and activities in developing a service-mindedness among prospective lawyers towards legal aid work. Particularly the Principles and Guidelines advances a collaborative approach between the government and law schools of the country. This collaboration is able to develop a sense of responsibility among the students to render legal services for the poor. It is also expected to increase the outreach and quality of the service. It has been further shown that the Bar Council of India has mandated legal aid activities within the academic curricula of law schools. ${ }^{83}$ The NALSA has also made it obligatory for law schools to establish legal aid clinics by the adoption of the National Legal Services Authority (Legal Aid Clinics) Scheme, 2011. As a result, despite various drawbacks, some Indian law schools have established exemplary practices with regard to the establishment and conduct of effective legal aid

\footnotetext{
${ }^{82}$ L. B. Rahman, 'To improve legal education', The Daily Star (online), Dhaka, Bangladesh, February 17, 2015. http://www.thedailystar.net/law-and-our-rights/to-improve-legal-education-65253 (accessed on 18 February 2015).

${ }^{83}$ See section 3.
} 


\section{Practice Report: Teaching and Learning in Clinic}

clinics. In Bangladesh, the LASA does not have any specific provision that requires legal aid services to be integrated into the legal education of the country in order to equip future lawyers with adequate service orientation and motivation. More specifically, the NLASO has not approached the Bar Council ${ }^{84}$ or the University Grants Commission or issued any resolution to include the scheme of law clinics as a mandatory part of the academic curriculum. Therefore, it can be said that, as regards the integration of legal aid activity, the current standard of Indian legal education is more advanced than Bangladesh. However, the strategic plan of the NLASO includes that the organisation aims to work for the integration of legal aid activities in law school curricula. Although the plan is not clear as to how the current legal education system would be rearranged in order to contribute to legal services for the poor, the NLASO has started to cooperate with various student legal aid forums. It has organised workshops or seminars on different occasions. ${ }^{85}$ This kind of initiative is commendable but the lack of provision in the LASA or the taking of concrete steps to incorporate legal aid clinics as a compulsory component is not able to produce any tangible and durable development in

\footnotetext{
${ }^{84}$ There are three bodies that regulate the legal profession in Bangladesh: the district Bar Association in each district, Supreme Court Bar Association in the Supreme Court and the central institution is the Bangladesh Bar Council. The Bar Council issues licenses to lawyers, and monitors the disciplinary and welfare activities of all lawyers.

${ }^{85}$ News of different events and activities of the NLASO and in general of the government legal aid services are posted in a Facebook group, 'National Legal Aid Forum.' Officials of the NLASO are actively involved in the administration of this group. The link to the group ishttps://web.facebook.com/groups/173549189481223/ (accessed on 20 April 2016).
} 


\section{Practice Report: Teaching and Learning in Clinic}

Bangladeshi legal education for providing legal aid to the poor. Therefore, the current provision of the LASA is not comprehensive with regard to the integration of legal aid activities in law school curricula as envisaged by international human rights standards. This requires the NLASO to take more vigilant initiatives so that law schools can be an effective avenue to render legal services to the poor.

\section{CONCLUSION}

Legal education builds the foundation of the service the legal community offers to any nation. ${ }^{86}$ If law students at the formative stage of their career are exposed to legal aid services, they become motivated to deliver the service when they enter into professional life. International human rights norms have also recognised the role of legal education in creating a profession with sincere appreciation and commitment to the need to provide legal services to the poor. Legal education in Bangladesh, therefore, is required to explore the potential of clinical legal education with a compulsory component of legal aid programme as demonstrated by international human rights standards. The NLASO, University Grants Commission and Bar Council should make coordinated efforts to make this programme real and effective. In addition, Bangladesh should follow the standard practices of particular Indian law schools. However, given the

\footnotetext{
${ }^{86}$ R. Hoque, Supra note 81.
} 


\section{Practice Report: Teaching and Learning in Clinic}

drawbacks in the Indian system, Bangladesh should take appropriate measures so that clinical legal education programmes become a credit-earning course for the students. Also, incentives should be provided to allow students to represent legal aid clients before the Courts under the supervision of a senior lawyer or a law professor. Law schools should undertake programmes to organise legal literacy camps and make adequate efforts for informing the community about their existence and the kind of services they offer. Thus, law schools and legal aid committees can complement each other in the conduct of the legal services programme in Bangladesh. 